Keywords:

Forest products

adsorbent development water treatment

Histórico:

Recebido 25/10/2016

Aceito 03/03/2017

Palavras chave:

Produtos Florestais

Desenvolvimento de adsorventes Tratamento de água

Correspondência: gregorioengflorestal@gmail.com

DOI:
Gregório Mateus Santana', Roberto Carlos Costa Lelis', Emerson Freitas Jaguaribe², Rayssa de Medeiros Morais', Juarez Benigno Paes ${ }^{3}$, Paulo Fernando Trugilho ${ }^{4}$

\section{DEVELOPMENT OF ACTIVATED CARBON FROM BAMBOO (Bambusa vulgaris) FOR PESTICIDE REMOVAL FROM AQUEOUS SOLUTIONS}

ABSTRACT: Considering the water scarcity problems facing many countries, the need for water reuse can make activated carbon (AC) an essential product for modern society. In this context, to contribute with better activated carbons that could be used to serve in water treatment, this article discusses these materials production, using bamboo as raw material, and analyses their application effectiveness. The bamboo was collected, transformed into activated carbon, by simultaneous chemical and physical activations, and named $\mathrm{H}_{3} \mathrm{PO}_{4} /$ $\mathrm{H}_{2} \mathrm{OAC}$. The obtained material was characterized by its yield, apparent density, ash content, thermogravimetric analysis, surface area, methylene blue and iodine indexes, $\mathrm{pH}$ and point of zero charge analysis, scanning electron microscopy and Boehm titration method. The AC was used as adsorbent for removing the metribuzin, 2,4-dichlorophenoxyacetic acid and furadan pesticides. The $\mathrm{H}_{3} \mathrm{PO}_{4} / \mathrm{H}_{2} \mathrm{OAC}$ had a surface area of $1196.30 \mathrm{~m}^{2} \cdot \mathrm{g}^{-1}$ and the obtained adsorption capacity was elevated for furadan $\left(868.98 \mathrm{mg} \cdot \mathrm{g}^{-1}\right)$, metribuzin $\left(756.47 \mathrm{mg} \cdot \mathrm{g}^{-1}\right)$ and 2,4-dichlorophenoxyacetic acid $\left(274.70 \mathrm{mg} \cdot \mathrm{g}^{-1}\right)$.

\section{DESENVOLVIMENTO DE CARVÃO ATIVADO A PARTIR DE BAMBU (Bambusa vulgaris) PARA REMOÇÃO DE PESTICIDAS DE SOLUÇÕES AQUOSAS}

RESUMO: Considerando os problemas de escassez de água enfrentados por vários países, a necessidade de reuso das águas, pode fazer do carvão ativado (CA) um produto imprescindível à sociedade moderna. Neste contexto, para contribuir com a melhoria de carvões ativados que poderão servir ao tratamento de água, este artigo, discute a produção desses materiais, que teve o bambu, como matéria prima, e analisa a eficácia de sua aplicação. O bambu foi coletado, transformado em carvão ativado mediante ativação química e física simultânea e denominado $\mathrm{CA} \mathrm{H}_{3} \mathrm{PO}_{4} / \mathrm{H}_{2} \mathrm{O}$. O material obtido foi caracterizado pelo rendimento, densidade aparente, teor de cinzas, análise termogravimétrica, área superficial, índices de azul de metileno e de iodo, análise do $\mathrm{pH}$ e ponto de carga zero, microscopia eletrônica de varredura e método titulométrico de Boehm. O CA foi usado como adsorvente para a remoção dos pesticidas metribuzin, 2,4-diclorofenoxiacético e furadan. $\mathrm{O} \mathrm{CA} \mathrm{H}_{3} \mathrm{PO}_{4} / \mathrm{H}_{2} \mathrm{O}$ apresentou área superficial de I 196,30 $\mathrm{m}^{2} \cdot \mathrm{g}^{-1}$ e a capacidade de adsorção obtida foi elevada para o furadan $(868,98$ $\left.\mathrm{mg} \cdot \mathrm{g}^{-1}\right)$, metribuzin $\left(756,47 \mathrm{mg} \cdot \mathrm{g}^{-1}\right)$ e 2,4 -diclorofenoxiacético $\left(274,70 \mathrm{mg} \cdot \mathrm{g}^{-1}\right)$.

' Federal Rural University of Rio de Janeiro - Seropédica, Rio de Janeiro, Brazil

2 Federal University of Paraiba - João Pessoa, Paraíba, Brazil

${ }^{3}$ Federal University of Espirito Santo - Jerônimo Monteiro, Espírito Santo, Brazil

${ }^{4}$ Federal University of Lavras -Lavras, Minas Gerais, Brazil 


\section{INTRODUCTION}

In recent years, there has been a rising expansion of the activated carbon (AC) global market. According to the Transparency Market Research (TMR), the product transactions reached, in 2012, I.913 billion dollars and the predictions are that at the end of 2019 the numbers surpass the mark of 4.180 billion, presenting an annual increase rate of $11.9 \%$ in the 2013-2019 period. Moreover, if $42.14 \%$ of the world market volume in 2012 was directed for water treatment and for $35.21 \%$ air purification, there is a tendency for the activated carbon market to advance towards the food, pharmaceutical and medical industry (TMR, 2016).

$A C$ is a highly porous carbonaceous material, with an elevated internal surface area and functional groups in its surface with an adsorption affinity for various contaminants. AC is obtained from controlled pyrolysis of a raw material, where temperatures vary from 400 to $1000{ }^{\circ} \mathrm{C}$, and consequent physical and chemical activation (RIBEIRO, 2005; BRUM et al., 2008; AVELAR et al., 20I0; COUTO et al., 20I2; CARVAJAL-BERNAL et al., 2015; NOBRE et al., 20I5; HÚMPOLA et al., 20I6).

There are two ways of using activated carbon: liquid and gas. The most known applications are water treatment (remedying bodies of water, effluent treatment and sanitary landfill and water filters lixiviate); air purification (toxic gases and combustion gases removal); food and drink industrialization (sweetener purification, edible oils, glycerin, wine, organic and inorganic acids); pharmaceutical production (color and compounds removal from some drugs); medicinal use (toxic products elimination; tablets, curatives, odor control filters and masks productions), use in automotive vehicles (adsorbing combustible emissions or inside odors from them). It also is useful on oil refineries as a support for catalysts, gas storage, dehumidification (mold elimination and food conservation); in mining; and in the electronic industry (AVELAR et al., 2010; SALES et al., 2012; BAUTISTA-TOLEDO et al., 20I4; SAUCIER et al., 2015; TMR, 2016).

In Brazil, there seems to be a limited number of researches and industries compromised with the development or production of first quality AC. In other words, AC that can be used in applications that demand, for example, specific pore distribution. For these reasons, the country is considered an emergent market in activated carbon production, with limited production and that has a median or low quality. Thus, to satisfy the national demand, there is an increasing rise in the product imports.
At the same time, there is a constant worry with rising water contamination, such as in the Guanabara Bay, in city, or the ones caused by sudden environmental disasters, such as the dam breakage of the Samarco Mining Company that affected the Doce River, which basin is the biggest of the southeast region of the country. Depollution projects of those water sources depend on much elaborated politics that revolves around population awareness and water treatment. New technologies that use $A C$ are indispensable for removing pollutants that are causing increasing severe environmental damage (CARVAJAL-BERNAL et al., 20I5; SAUCIER et al., 20I5; HÚMPOLA et al., 2016; WERNERT; DENOYEL, 2016).

Bamboo use as a raw material for developing (production, characterization and application) of $A C$ is relevant, for being a species with high presence of carbon and fibrovascular bundles, responsible for forming the activated carbon porous carbonaceous structure, among other characteristics such as fast grow, high productivity and small production circles.

In 201I, the Brazilian government sanctioned a law project that instituted the National Politic of Incentive to the Bamboo Sustainable Management and Cultivation, the "Bamboo Law" n. ${ }^{\circ}$ I 2484 (TIBURTINO et al., 20I5). This act aims, among others, to stimulate the technological development and innovation of bamboo products.

In this context, to contribute with better activated carbons that could be used for water treatment, this article discusses these materials production, using bamboo as raw material, and analyses their application effectiveness.

\section{MATERIAL AND METHODS}

\section{Raw material}

Bamboo (Bambusa vulgaris) came from two-yearold plantations of the Celulose e Papel de Pernambuco S.A. (CEPASA) company, that belongs to Grupo Industrial João Santos, located at the municipality of Jaboatão dos Guararapes, Pernambuco state, Brazil. The material was cleaned with running water, dried in a shaded area, grinded and classified in 4; 8; 30; 40; 60 and 100 mesh sieves. The used fraction for producing $A C$ was the one that passed on the 8 mesh sieve and was retained on the 30 mesh.

\section{Variables of the process and activated carbon production}

A total of five variables of the process were controlled: I activating agent / raw material ratio; 2 activation temperature; 3 heating rate; 4 residence time; 
and 5 fluxes of steam and $\mathrm{N}_{2}$ gas. Thus, the raw material was impregnated with $\mathrm{H}_{3} \mathrm{PO}_{4}$ concentration solution at 2: I (m:m), under agitation at $80{ }^{\circ} \mathrm{C}$ for 2 hours. Then, it was dried in a conventional oven at $103 \pm 2{ }^{\circ} \mathrm{C}$, for 24 hours. After that, the obtained material was activated in a rotating electric oven (CHINO), containing a tubular reactor, an electric boiler and an attached dewar container with $\mathrm{N}_{2}$ (Figure I).

The activation process occurred at a final temperature of $500{ }^{\circ} \mathrm{C}$, with a $10^{\circ} \mathrm{C} \cdot \mathrm{min}^{-1}$ heating rate, 60 min residence time with a $100 \mathrm{~mL} \cdot \mathrm{min}^{-1}$ steam water flux and $80 \mathrm{~mL} \cdot \mathrm{min}^{-1} \mathrm{~N}_{2}$ flux for all the activations. In the process, six repetitions were used. At the end of the process, the oven was turned off, the $\mathrm{N}_{2}$ flux maintained until $300^{\circ} \mathrm{C}$ and the $\mathrm{AC}$ taken off the oven after $150^{\circ} \mathrm{C}$.

The $\mathrm{AC}$, named $\mathrm{H}_{3} \mathrm{PO}_{4} / \mathrm{H}_{2} \mathrm{OAC}$, was washed with distilled water, alternating hot and cold temperatures, until neutral $\mathrm{pH}$. Finally, the mass of $\mathrm{AC}$ was dried in a kiln at $103 \pm 2{ }^{\circ} \mathrm{C}$, for 24 hours, and the AC yield (\%) was determined according to Equation ( $\mathrm{I})$, where: $\mathrm{m}_{\mathrm{f}}$ : final dried mass $(\mathrm{g})$ of $\mathrm{H}_{3} \mathrm{PO}_{4} / \mathrm{H}_{2} \mathrm{OAC}$; $\mathrm{m}_{0}$ : initial dried mass $(\mathrm{g})$ of the raw material.

Yield $(\%)=\frac{m_{f}}{m_{0}} \cdot 100$

\section{Apparent density, ash content and thermogravimetic analysis}

For apparent density (d), the AC was initially macerated, classified in a 40 mesh sieve and introduced in a previously weighted test tube, submitted to light lateral impacts until there were no variations in the compacted volume. The $d$ was obtained by dividing the mass ( $g$ ) AC by the volume $\left(\mathrm{cm}^{-3}\right)$ occupied in the test tube.

For evaluating the ash content (AsC), about I $\mathrm{g}$ of $\mathrm{H}_{3} \mathrm{PO}_{4} / \mathrm{H}_{2} \mathrm{OAC}$ was put in a crucible that was taken to a kiln at $103 \pm 2{ }^{\circ} \mathrm{C}$, where it stood for I hour and
30 minutes. The sample was transferred to a desiccator for cooling. The AsC was determined by the material combustion used at $750{ }^{\circ} \mathrm{C}$, for $6 \mathrm{~h}$, in a muffle oven, according to Brazilian Regulatory Standard - NBR 8I I2, Brazilian Technical Norms Association - ABNT (1986). At the end of the process, the material was cooled on a desiccator for 20 minutes, when the $\mathrm{AsC}$ was calculated from the inorganic residue division by the dried mass of the $\mathrm{H}_{3} \mathrm{PO}_{4} / \mathrm{H}_{2} \mathrm{OAC}$, expressed in percentage.

The thermal decomposition behavior of the material was evaluated with a thermal balance (TGA-Q50 model, from TA Instruments). For such, a sample of about $10 \mathrm{mg}$ of the activated carbon was placed into its platinum crucible and heated with a heating rate of $10^{\circ} \mathrm{C} \cdot \mathrm{min}^{-1}$, from 25 to $900^{\circ} \mathrm{C}$, under a $50 \mathrm{~mL} \cdot \mathrm{min}^{-1} \mathrm{~N}_{2}$ flux.

\section{Surface areas, volume and pore diameter}

A porosimeter (ASAP 2020 model from Micromeritics) was used to determine the BET surface area $\left(\mathrm{S}_{\mathrm{BET}}\right)$ - based on $\mathrm{N}_{2}$ at $77 \mathrm{~K}$ (SKAAR, 1988) - the microporous area $\left(S_{M}\right)$, the Langmuir surface area $\left(\mathrm{S}_{\text {Langmuir }}\right)$, the external surface $\left(\mathrm{S}_{\text {external }}\right)$, the total pore $\left(\mathrm{V}_{\mathrm{p}}\right)$, the micropore $\left(\mathrm{V}_{\mathrm{MP}}\right)$ and mesopore $\left(\mathrm{V}_{\mathrm{MSP}}\right)$ volumes and the average pore diameter (D) of the $\mathrm{H}_{3} \mathrm{PO}_{4} / \mathrm{H}_{2} \mathrm{OAC}$. The sample was degasified at $250{ }^{\circ} \mathrm{C}$.

\section{Estimated surface areas by the methylene blue and iodine indexes}

The surface area formed by mesopores and some micropores (the methylene blue molecule has a minimum diameter of nearly $0.8 \mathrm{~nm}$ ) was first estimated from the methylene blue (MB) adsorption and calculated according to the Equation 2, where: $\mathrm{S}_{\mathrm{MB}}$ : estimated surface area by the methylene blue $\left(\mathrm{m}^{2} \cdot \mathrm{g}^{-1}\right)$ index; $\mathrm{S}_{\mathrm{MB}}$ : surface area of the methylene blue $\left(\mathrm{S}_{\mathrm{MB}}^{\circ}=1.93 \mathrm{~m}^{2} \cdot \mathrm{g}^{-1}\right)$; and $\mathrm{q}_{\mathrm{m}}$ : maximum methylene blue adsorption capacity $\left(\mathrm{mg}^{\circ} \mathrm{g}^{-1}\right)$ by $\mathrm{AC}$.

$\mathrm{S}_{\mathrm{MB}}=\mathrm{S}_{\mathrm{MB}}^{o} \cdot \mathrm{q}_{\mathrm{m}}$

[2]

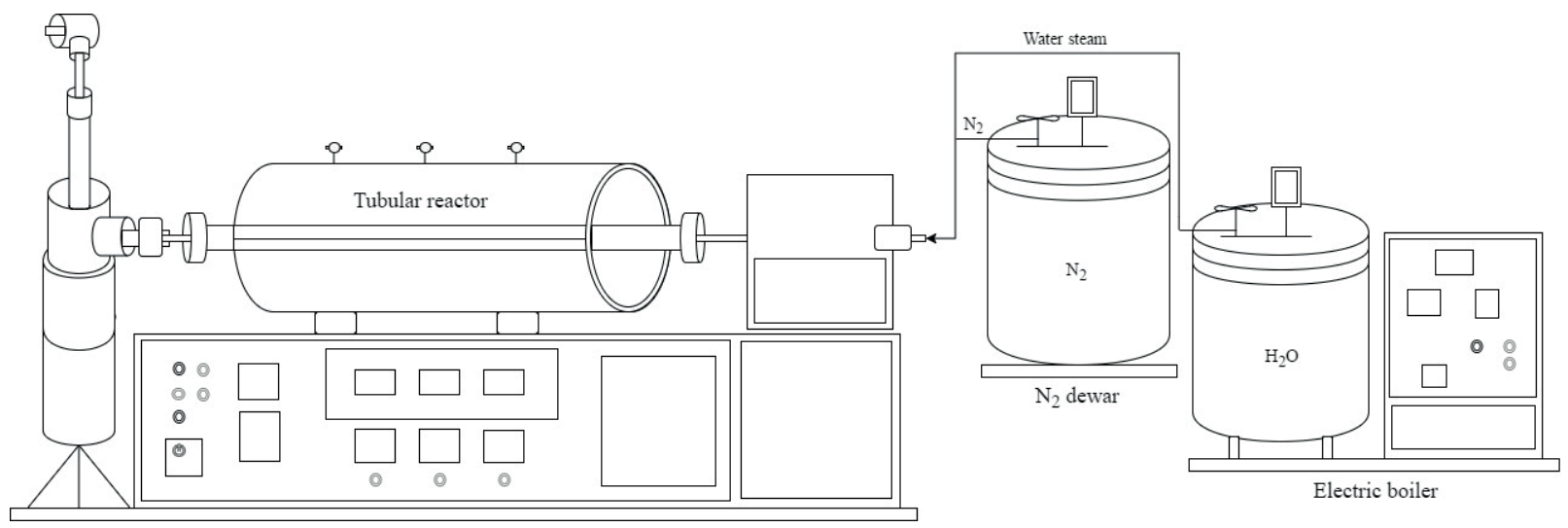

FIGURE I Rotating electric oven schematic representation used for the activation. 
The iodine number (I) evaluates the AC micropores surface area (its molecule is rated as of small diameter, roughly $0.56 \mathrm{~nm}$ ). For its determination, a 250 $\mathrm{mL}$ Erlenmeyer, previously dried, was used with a sample of $1.0 \mathrm{~g}$ of $\mathrm{AC}$ and $10 \mathrm{~mL}$ of $\mathrm{HCl}$ at $20 \%$. The material was stirred and the formed suspension heated up to 150 ${ }^{\circ} \mathrm{C}$ and kept for 30 seconds in ebullition. Thus, a 100 $\mathrm{mL}$ of a standard iodine solution at $0.1 \mathrm{~N}$ was added. The solution was vigorously stirred for 30 seconds, and then, the sample was filtered in a glass funnel fitted with qualitative paper filter.

An aliquot of $50 \mathrm{~mL}$ of the filtered solution was transferred to a $250 \mathrm{~mL}$ Erlenmeyer. Then, it was titrated with a $0.1 \mathrm{~N}$ sodium thiosulfate and $2 \mathrm{~mL}$ of a $0.5 \%$ starch indicator solution. The analysis was made in duplicate and, in possession of the total volume of the sodium thiosulfate solution used in the titration, the iodine quantity $(\mathrm{mg})$ adsorbed by each $\mathrm{g}$ of the activated carbon was calculated, according to the American Society for Testing and Materials - ASTM D 4607 (1994).

\section{$\mathrm{pH}$ and point of zero charge determination}

For the $\mathrm{pH}$ evaluation, a sample of about I $\mathrm{g}$ of the $A C$ was transferred to a $250 \mathrm{~mL}$ Erlenmeyer and $100 \mathrm{~mL}$ of distilled water was added. The mixture was heated, kept in ebullition for 5 minutes and cooled to room temperature. Then, another $100 \mathrm{~mL}$ of distilled water was added and the $\mathrm{pH}$ of the solution was measured, using a digital $\mathrm{pH}$ meter, the DM-22 model from DIGIMED. The analysis was carried out in triplicate.

For $\mathrm{pH}$ point of zero charge $\left(\mathrm{pH}_{\mathrm{PZC}}\right)$ determination, about $0.3 \mathrm{~g}$ of the produced material was transferred to a $100 \mathrm{~mL}$ container and then $50 \mathrm{~mL}$ of $\mathrm{NaCl} 0.0 \mathrm{l} \mathrm{mol} \cdot \mathrm{L}^{-1}$ aqueous solution was added. The $\mathrm{NaCl}$ solution $\mathrm{pH}$ was adjusted to $2,3,4,5,7$ and 9 values with $\mathrm{HCl}\left(0.0 \mathrm{l} \mathrm{mol} \cdot \mathrm{L}^{-1}\right.$ and $\left.0.1 \mathrm{~mol} \cdot \mathrm{L}^{-1}\right)$ and $\mathrm{NaOH}\left(0.1 \mathrm{~mol} \cdot \mathrm{L}^{-1}\right)$ solutions, from a bench $\mathrm{pH}$ meter, a MPA 210 model from MS Tecnopon.

The container was sealed shut and agitated in a Shaker incubator (SL 22I model from SOLAB) with agitation control of $100 \mathrm{rpm}$ and $25^{\circ} \mathrm{C}$ temperature during 24 hours. Later, the balance solution $\mathrm{pH}$ was measured and the chart was produced, disposing the final $\mathrm{pH}$ (Y-axis) versus the initial $\mathrm{pH}(\mathrm{X}$-axis). The point of zero charge is the $\mathrm{pH}$ where the curve crosses the line in which the initial $\mathrm{pH}$ is the same as the final. The analysis was carried out in triplicate.

\section{Boehm method and scanning electron microscopy}

The determination of the functional surface groups followed the Boehm titrimetric method (1994).
In $0.25 \mathrm{~g}$ of $\mathrm{H}_{3} \mathrm{PO}_{4} / \mathrm{H}_{2} \mathrm{OAC}, 10 \mathrm{~mL}$ of $\mathrm{NaOH}, \mathrm{Na}_{2} \mathrm{CO}_{3}$, $\mathrm{NaHCO}_{3}$ (all at $0.05 \mathrm{~mol} \cdot \mathrm{L}^{-1}$ ) were added and the material was maintained at agitation at $25^{\circ} \mathrm{C}$ for 24 hours in a Shaker incubator (SL 221 model from SOLAB). After the agitation, the material was filtered with a filter paper (80 $\mathrm{g} \cdot \mathrm{m}^{-2}$ gramature, $205 \mu \mathrm{m}$ thickness, $14 \mu \mathrm{m}$ pores) and 5 $\mathrm{mL}$ rates were taken. In the $\mathrm{NaOH}$ and $\mathrm{NaHCO}_{3}$ rates, $10 \mathrm{~mL}$ of $\mathrm{HCl}\left(0.05 \mathrm{~mol} \cdot \mathrm{L}^{-1}\right)$ and in $\mathrm{Na}_{2} \mathrm{CO}_{3} 15 \mathrm{~mL}$ of $\mathrm{HCl}\left(0.05 \mathrm{~mol} \cdot \mathrm{L}^{-1}\right)$ were added. Next, they were titrated with $\mathrm{NaOH}\left(0.05 \mathrm{~mol} \cdot \mathrm{L}^{-1}\right)$ and the $\mathrm{NaOH}$ and $\mathrm{HCL}$ standardize. The acid group number was determined considering the sodium hydroxide, $\mathrm{NaOH}$, neutralizes carboxylic acids, lactones and phenols; and the sodium carbonate, $\mathrm{Na}_{2} \mathrm{CO}_{3}$, acts in the carboxylic acids and lactones, while the sodium bicarbonate only neutralized carboxylic acids.

The superficial morphology of the material was obtained by scanning electron microscopy in a FEl Quanta 450, using $20 \mathrm{kv}$ tension. For such, the samples were mounted in an aluminum platform using a double carbon strip with a thin gold layer deposited by Emitech K550X sputter.

\section{Activated carbon application and adsorption kinetics evaluation}

To evaluate the ability of the $\mathrm{AC}\left(\mathrm{H}_{3} \mathrm{PO}_{4} / \mathrm{H}_{2} \mathrm{OAC}\right)$ in the water treatment, adsorption experimental tests with three different pesticides were carried out (Table I). In order to explore the adsorption kinetics, $10 \mathrm{mg}$ of $\mathrm{AC}$ were mixed with $10 \mathrm{~mL}$ of distinct solutions based on the MTZ, 2,4-D and FRD having, each one, a concentration of $50 \mathrm{mg} \cdot \mathrm{L}^{-1}$. The containers were sealed shut and stirred in a shaker (SL 22 I, SOLAB) at $100 \mathrm{rpm}$ and temperature of $25^{\circ} \mathrm{C}$.

TABLE I Employed pesticides characteristics.

\begin{tabular}{ccccc}
\hline Pesticides & Abbreviation & Nature & $\mathrm{M}\left(\mathrm{g} \cdot \mathrm{mol}^{-1}\right)$ & $\lambda(\mathrm{nm})$ \\
\hline Metribuzin & MTZ & Herbicide & 214.29 & 294 \\
2,4-dichlorophenoxyacetic & $2,4-D$ & Herbicide & 221.04 & 283 \\
Furadan & FRD & Insecticide & 221.25 & 276 \\
\hline
\end{tabular}

At predetermined intervals of $1 ; 3 ; 6 ; 12$ and 24 hours, samples of the solution having each about 3.5 $\mathrm{mL}$ were taken and its concentrations determined. The contaminant concentration was evaluateded using a spectrophotometer UV-VIS (UV-mini I240, SHIMADZU).

\section{Adsorption isotherms}

The adsorption isotherms were obtained using $10 \mathrm{mg}$ of $\mathrm{AC}$ and $10 \mathrm{~mL}$ of solutions having different concentration of MTZ, 2,4-D and FRD. The samples were stored in $20 \mathrm{~mL}$ recipients, kept under $100 \mathrm{rpm}$ 
rotation in a shaker (SL 22I, SOLAB) for 24 hours, and at temperature of $25^{\circ} \mathrm{C}$. The equilibrium concentration was performed by an UV-VIS (UV-mini I240, SHIMADZU) by employing appropriate wavelength $(\lambda)$ for each contaminant in a punctual analysis of absorbance.

Calibration curves with concentrated solutions of 25; 50; 100; 250; 500 and $1000 \mathrm{mg} \cdot \mathrm{L}^{-1}$ for each adsorbate (MTZ, 2,4-D and FRD) were prepared. The quantity of adsorbate adsorbed per gram, $\mathrm{q}_{\mathrm{eq}}$, was calculated according to Equation 3, where: $C_{0}$ and $C_{e q}$ : represent, respectively, the initial and at balance concentrations (mg. $\left.\mathrm{L}^{-1}\right)$; $\mathrm{V}$ : the adsorbate volume (L); and $\mathrm{m}$ : the adsorbent mass (g).

$\mathrm{q}_{\mathrm{eq}}=\frac{\left(\mathrm{C}_{0}-\mathrm{C}_{\mathrm{eq}}\right) \cdot \mathrm{V}}{\mathrm{m}}$

\section{Applied models for data fitting}

The obtained data in the isotherms $\left(\mathrm{q}_{\mathrm{eq}}\right.$ and $C_{e q}$ ) were fitted to Langmuir and Freundlich models. Equation 4 describes the behavior of the Langmuir isotherm, while its linear form appears in Equation 5. On the other hand, Equation 6 represents the general form of the Freundlich model, which is conveniently linearized by the application of logarithms in two terms (Equation 7), where: $\mathrm{q}_{\mathrm{eq}}$ : the adsorbed quantity $\left(\mathrm{mg} \cdot \mathrm{g}^{-1}\right)$ for a given adsorbate concentration (MTZ, 2,4-D and FRD); $\mathrm{q}_{\mathrm{m}}$ : the maximum adsorption capacity ( $\mathrm{mg} \cdot \mathrm{g}^{-}$ '); $C_{\text {eq }}$ : adsorbate concentration after the equilibrium to be achieved $\left(\mathrm{mg} \cdot \mathrm{L}^{-1}\right) ; \mathrm{K}_{\mathrm{L}}$ : Langmuir constant; $\mathrm{K}_{\mathrm{F}}$ : sorption coefficient and $\mathrm{I} / \mathrm{n}$ : sorption intensity measure - Freundlich constants.

$q_{e q}=\frac{q_{m} \cdot K_{L} \cdot C_{e q}}{1+K_{L}+C_{e q}}$

$\frac{C_{e q}}{q_{e q}}=\frac{1}{q_{m} \cdot K_{L}}+\frac{1}{q_{m}} \cdot C_{e q}$

$\mathrm{q}_{\mathrm{eq}}=\mathrm{K}_{\mathrm{F}} \cdot \mathrm{C}_{\mathrm{eq}}^{1 / \mathrm{q}}$

$\log \left(\mathrm{q}_{\mathrm{eq}}\right)=\log \left(\mathrm{K}_{\mathrm{F}}\right)+\frac{1}{\mathrm{n}} \log \left(\mathrm{C}_{\mathrm{eq}}\right)$

\section{RESULTS AND DISCUSSION}

\section{Yield, apparent density, ash content and thermogravimetrical analyses}

The $\mathrm{H}_{3} \mathrm{PO}_{4} / \mathrm{H}_{2} \mathrm{OAC}$ showed elevated yield values $(39.00 \%)$ and apparent density $\left(0.50 \mathrm{~g} \cdot \mathrm{cm}^{-3}\right)$ and low ash content $(2.82 \%)$. The low ash content is a positive factor for the AC production, since the mineral matter, because of its hydrophilic characteristic, promotes the water adsorption competing with other compounds of interest (BRUM et al., 2008).

The thermogravimetrical analysis (TGA) registers a loss of mass of the material when submitted to a temperature program with time and temperature variation (SANTOS et al., 20I2). By the TGA of the produced $\mathrm{AC} \mathrm{H}_{3} \mathrm{PO}_{4} / \mathrm{H}_{2} \mathrm{O}$ by its temperature, it can be observed that the first mass declivity happened next to $100{ }^{\circ} \mathrm{C}$ in an outcome of the moisture loss (RAMOS et al., 2009). Then, there was the decomposition of the material next to the final activation temperature $\left(500^{\circ} \mathrm{C}\right)$ and the residual percentage of the $\mathrm{H}_{3} \mathrm{PO}_{4} / \mathrm{H}_{2} \mathrm{OAC}$ after the end of the analysis was around 62\% (Figure 2).

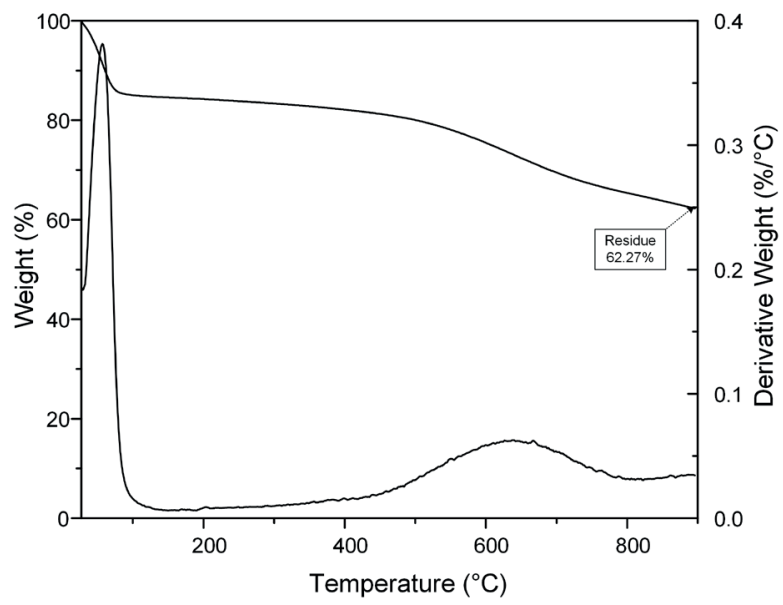

FIGURE 2 Thermogravimetrical analysis for the produced $\mathrm{H}_{3} \mathrm{PO}_{4} / \mathrm{H}_{2} \mathrm{OAC}$.

\section{Surface areas and porosity}

The $\mathrm{H}_{3} \mathrm{PO}_{4} / \mathrm{H}_{2} \mathrm{OAC}$ got a $618.72 \mathrm{mg} \cdot \mathrm{g}^{-1} \mathrm{~S}_{\mathrm{MB}}$ and $747.5 \mathrm{I} \mathrm{mg} \cdot \mathrm{g}^{-1} \mathrm{I}$, with the methylene blue being adsorbed in the bigger mesopores and micropores region of the $A C$, while the iodine, with smaller dimensions, adsorbed in the microporous region. The obtained result for I was very satisfactory, since the Brazilian Specification - EB 2I33, ABNT (I99I) requires that the iodine index $(\mathrm{I})$ be at least $600 \mathrm{mg} \cdot \mathrm{g}^{-1}$ for the $A C$.

The adsorption and desorption isotherms of $\mathrm{N}_{2}$ (Figure 3) indicated high adsorption at low $\mathrm{N}_{2}$ pressures, evidencing the micropores formation (RAMOS et al., 2009). Furthermore, the produced AC has $1196.30 \mathrm{~m}^{2} \cdot \mathrm{g}^{-1}$ BET surface area $-\mathrm{S}_{\mathrm{BET}} ; 884.88 \mathrm{~m}^{2} \cdot \mathrm{g}^{-1}$ micropores; $1593.25 \mathrm{~m}^{2} \cdot \mathrm{g}^{-1}$ Langmuir; $3 \mathrm{II} .42 \mathrm{~m}^{2} \cdot \mathrm{g}^{-1}$ external; $0.61 \mathrm{~cm}^{3} \cdot \mathrm{g}^{-1}$ total pore volume; $0.40 \mathrm{~cm}^{3} \cdot \mathrm{g}^{-1}$ total micropore volume; $0.15 \mathrm{~cm}^{3} \cdot \mathrm{g}^{-1}$ mesopores; and average diameter of $20.50 \AA$. The $\mathrm{S}_{\mathrm{BET}}$ was elevated 


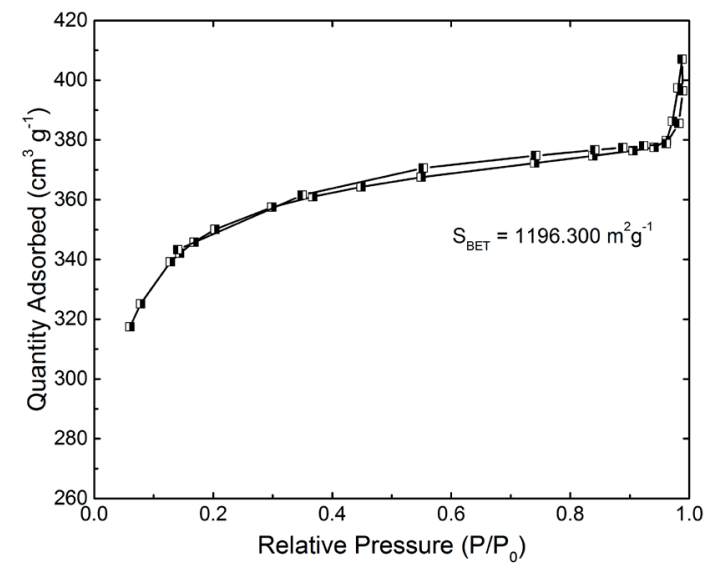

FIGURE 3 Adsorption/desorption isotherms of nitrogen $\left(\mathrm{N}_{2}\right)$ at $77 \mathrm{~K}$ for the produced $\mathrm{AC}$.

and could have great influence in the adsorption, because generally great superficial areas could mean great adsorption capacity (BARBOSA et al., 20I4).

Table 2 presents the surface area $\left(\mathrm{S}_{\mathrm{BET}}\right)$ of our produced $\mathrm{AC}$ and of some well-known adsorbents for removal of pesticides. Even if the $\mathrm{ACH}_{3} \mathrm{PO}_{4} / \mathrm{H}_{2} \mathrm{OAC}$ does not present higher BET surface area when compared to that of the others, it demonstrated to be more effective in removing FRD, MTZ and 2,4-D.

TABLE 2 Values of surface area $\left(S_{B E T}\right)$ and maximum adsorption capacity $\left(\mathrm{q}_{\mathrm{m}}\right)$ for different adsorbents for removal of pesticides.

\begin{tabular}{ccccc}
\hline Adsorbent & $\mathrm{S}_{\text {BET }}\left(\mathrm{m}^{2} \cdot \mathrm{g}^{-1}\right)$ & Pesticide & $\mathrm{q}_{\mathrm{m}}\left(\mathrm{mg} \cdot \mathrm{g}^{-1}\right)$ & Reference \\
\hline $\mathrm{H}_{3} \mathrm{PO}_{4} /$ & & *FRD & 868.98 & This study \\
$\mathrm{H}_{2} \mathrm{OAC}$ & $\mathrm{I} 196.30$ & MTZ & 756.47 & This study \\
Rice straw AC & 1304.80 & FRD & 312.50 & Chang et al. 20I4 \\
SFHAC & 1211.57 & Bentazon & 166.67 & Njoku et al. 20I4a \\
LEFBAC & 1065.65 & $2,4-D$ & 261.20 & Njoku et al. 2015 \\
DSAC & 880.18 & Bentazon & 86.26 & Salman et al. 20II \\
GAC F3000 & 731.48 & $2,4-D$ & 181.82 & Salman; Hameed, \\
CFAC & 483.00 & FRD & 198.40 & Njoku et al. 20I4b \\
Banana peels & - & MTZ & 167.00 & Ul Haq et al. 20I5 \\
AC & & &
\end{tabular}

* FRD $=$ Furadan; MTZ = Metribuzin and 2,4-D = 2,4-dichlorophenoxyacetic

\section{pH, point of zero charge and Boehm method analysis}

The AC from Bambusa vulgaris has an acid $\mathrm{pH}$ (2.90), which has origin in its agent of activation, i.e., the phosphoric acid. The $\mathrm{pH}$ is an important parameter, since it controls the electrostatic interactions between the adsorbate and the adsorbent, having great influence in the adsorption process (BAUTISTA-TOLEDO et al., 2005). The determined point of zero charge $\left(\mathrm{pH}_{\mathrm{PZC}}\right)$ was $2.4 \mathrm{I}$, which indicates that the material tends to present negative charges in solutions with $\mathrm{pH}$ higher than 2.4I. On the other hand, these charges become positive when the middle $\mathrm{pH}$ is lower than $\mathrm{pH}_{\mathrm{PZC}}$.
By the Boehm titration method, the $\mathrm{H}_{3} \mathrm{PO}_{4} / \mathrm{H}_{2} \mathrm{OAC}$ showed functional acid groups in its surface, with a total acidity of $1.804 \mathrm{mmol} \cdot \mathrm{g}^{-1}$. In terms of present higher quantities, the highlights were the carboxylic acids with $1.454 \mathrm{mmol} \cdot \mathrm{g}^{-1}$ and the phenolic groups with $0.140 \mathrm{mmol} \cdot \mathrm{g}^{-1}$.

\section{Scanning electronic microscopy}

The scanning electronic microscopy (SEM) analysis (Figure 4) showed the presence of an organized pore region in the fibrovascular bundle wall after the activation that permits the diffusion of the contaminants in a faster way to the inner regions of the produced $\mathrm{H}_{3} \mathrm{PO}_{4} / \mathrm{H}_{2} \mathrm{OAC}(\mathrm{A})$. Besides, when the scale is increased, it is verified in the bundle wall the occurrence of region with protuberances that enhances the contact surface of the $A C$ with the contaminants $(B)$.

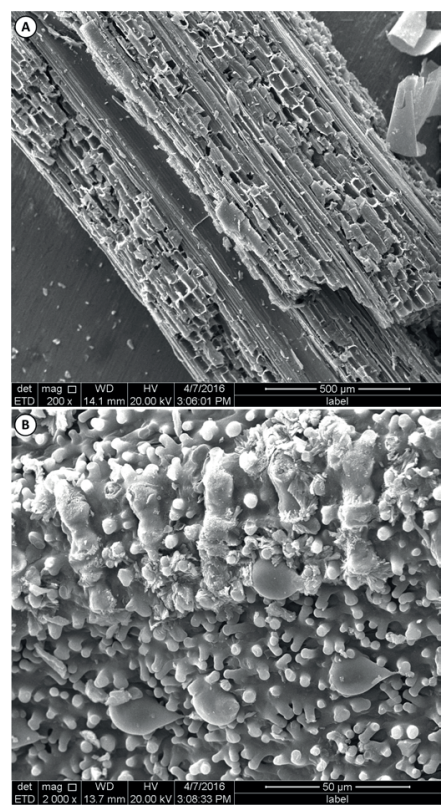

FIGURE 4 Surface morphology of $\mathrm{H}_{3} \mathrm{PO}_{4} / \mathrm{H}_{2} \mathrm{OAC}$ obtained by scanning electronic microscopy for a $20 \mathrm{kv}$ tension. Presence of an organized pore network (A) and regions with protuberances in the wall of the fibrovascular bundle of $\mathrm{H}_{3} \mathrm{PO}_{4} / \mathrm{H}_{2} \mathrm{OAC}(\mathrm{B})$.

\section{Activated carbon applications and adsorption kinetics}

For the MTZ, the $\mathrm{H}_{3} \mathrm{PO}_{4} / \mathrm{H}_{2} \mathrm{OAC}$ presented a removal percentage, in I hour, superior than $60 \%$, with the filling of active sites of the produced $A C$ happening at a fast rate. For the 2,4-D and FRD, there was a slower removal, requiring more time (Table 3 ).

The removed contaminant rate was increased with the pesticide/activated carbon contact time. The balance is reached at different times but, within 24 hours of reaction, it was verified that the systems were at balance for 2,4-D (96.69\%), MTZ (92.90\%) and FRD (92.27\%). 
TABLE 3 Kinetic adsorption for the MTZ, 2,4-D and FRD for the adsorbate/adsorbent contact time ( $10 \mathrm{mg}$ of AC; $10 \mathrm{~mL} 50$ $\mathrm{mg} \cdot \mathrm{L}^{-1}$ solution; $\left.25^{\circ} \mathrm{C}\right)$.

\begin{tabular}{|c|c|c|c|c|c|c|c|c|c|}
\hline \multicolumn{10}{|c|}{ Adsorption kinetics for each pesticide } \\
\hline \multirow{2}{*}{ Exposure time (Hours) } & \multicolumn{3}{|c|}{ MTZ } & \multicolumn{3}{|c|}{ 2,4-D } & \multicolumn{3}{|c|}{ FRD } \\
\hline & ${ }^{*} \mathrm{C}_{\mathrm{eq}}$ & $\mathrm{q}_{\mathrm{eq}}$ & $\mathrm{R}(\%)$ & $\mathrm{C}_{\text {eq }}$ & $\mathrm{q}_{\mathrm{eq}}$ & $\mathrm{R}(\%)$ & $\mathrm{C}_{\mathrm{eq}}$ & $\mathrm{q}_{\mathrm{eq}}$ & $\mathrm{R}(\%)$ \\
\hline $\mathrm{I}$ & 18.03 & 31.97 & 63.93 & 22.31 & 27.69 & 55.37 & 25.57 & 24.43 & 48.86 \\
\hline 3 & 15.85 & 34.15 & 68.31 & 12.26 & 37.74 & 75.48 & 14.77 & 35.23 & 70.45 \\
\hline 6 & 5.19 & 44.81 & 89.62 & 7.16 & 42.84 & 85.67 & 6.82 & 43.18 & 86.36 \\
\hline 12 & 3.83 & 46.18 & 92.35 & 3.58 & 46.42 & 92.84 & 5.11 & 44.89 & 89.77 \\
\hline 24 & 3.55 & 46.45 & 92.90 & 1.65 & 48.35 & 96.69 & 3.86 & 46.14 & 92.27 \\
\hline
\end{tabular}

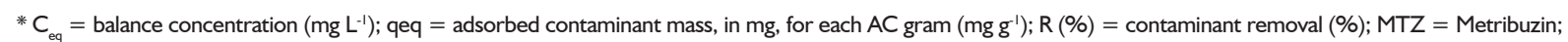
2,4-D = 2,4-dichlorophenoxyacetic; and FRD = Furadan.

\section{Adsorption isotherms and applied models}

The Langmuir and Freundlich parameters are described in Table 4 and the adsorption isotherms for MTZ (A), 2,4-D (B) and (C) FRD are presented in Figure 5. The $\mathrm{H}_{3} \mathrm{PO}_{4} / \mathrm{H}_{2} \mathrm{OAC}$ had elevated maximum adsorption capacity $\left(\mathrm{q}_{\mathrm{m}}\right)$ for the FRD $\left(868.98 \mathrm{mg} \cdot \mathrm{g}^{-1}\right)$, MTZ (756.47 $\left.\mathrm{mg} \cdot \mathrm{g}^{-1}\right)$ and 2,4-D $\left(274.70 \mathrm{mg} \cdot \mathrm{g}^{-1}\right)$. As well in the higher analyzed concentration ( $\left.1000 \mathrm{mg} \cdot \mathrm{L}^{-1}\right)$ it showed elevated values of $\mathrm{q}_{\mathrm{eq}}$ for the FRD $\left(590.67 \mathrm{mg} \cdot \mathrm{g}^{-1}\right)$, MTZ (519.31 $\left.\mathrm{mg} \cdot \mathrm{g}^{-1}\right)$ and 2,4-D (280.1 I mg. $\left.\mathrm{g}^{-1}\right)$.

The adsorption isotherms are basic requirements for the understanding of the adsorption process. The isotherm indicates how the molecules are distributed between the liquid and the solid stage when the adsorption reaches the balance status (MEZOHEGYI et al., 20I2). By the isotherms and $R^{2}$ values obtained, it can be noted that the MTZ and the FRD had a better adjustment to the Freundlich isotherm and the 2,4-D a better adjustment for Langmuir (Figure 5, Table 3).

The better adjustment for the Freundlich model shows that the adsorption happens in heterogenic and not specified sites of $\mathrm{H}_{3} \mathrm{PO}_{4} / \mathrm{H}_{2} \mathrm{OAC}$ (BARBOSA et al., 2014). For the better Langmuir adjustment, however, it is proposed a monolayer of the 2,4-D pesticide in the $\mathrm{H}_{3} \mathrm{PO}_{4} / \mathrm{H}_{2} \mathrm{OAC}$ surface, in which all the sites are identical and energetically equivalents.

The most important activated carbon characteristics for the contaminant adsorption are the superficial area, pore distribution, surface chemistry and mineral component (DIAS et al., 2007). The

TABLE 4 Physical-chemical parameters of adsorption obtained from the fitting to the Langmuir and Freundlich models for the three used pesticides.

\begin{tabular}{|c|c|c|c|c|c|c|}
\hline \multirow[b]{3}{*}{ Pesticides } & \multicolumn{6}{|c|}{ Adsorption parameters for the fitted models } \\
\hline & \multicolumn{3}{|c|}{ Langmuir } & \multicolumn{3}{|c|}{ Freundlich } \\
\hline & $\begin{array}{c}{ }^{*} \mathrm{q}_{\mathrm{m}} \\
\left(\mathrm{mg} \cdot \mathrm{g}^{-1}\right)\end{array}$ & $\begin{array}{c}\mathrm{K}_{\mathrm{L}} \\
\left(\mathrm{L} \cdot \mathrm{mg}^{-1}\right)\end{array}$ & $\mathrm{R}^{2}$ & $\mathrm{I} / \mathrm{n}$ & $\begin{array}{c}\mathrm{K}_{\mathrm{F}} \\
{\left[\left(\mathrm{mg} \mathrm{L}^{-1}\right)\left(\mathrm{L} \mathrm{mg}^{-1}\right)^{1 / n}\right]}\end{array}$ & $\mathrm{R}^{2}$ \\
\hline MTZ & 756.47 & 0.004 & 0.960 & 0.516 & 21.050 & 0.995 \\
\hline $2,4-D$ & 274.70 & 0.053 & 0.971 & 0.251 & 57.34 & 0.922 \\
\hline FRD & 868.98 & 0.005 & 0.982 & 0.549 & 22.499 & 0.997 \\
\hline
\end{tabular}

* $\mathrm{q}_{\mathrm{m}}=$ Maximum adsorption capacity $\left(\mathrm{mg} \cdot \mathrm{g}^{-1}\right) ; \mathrm{K}_{\mathrm{L}}=$ Langmuir constant; $\mathrm{R}^{2}=$ Correlation coefficient; $\mathrm{I} / \mathrm{n}=$ Freundlich parameter; $\mathrm{K}_{\mathrm{F}}=$ Freundlich constant; MTZ = Metribuzin; 2,4-D = 2,4-dichlorophenoxyacetic and FRD = Furadan. observed results suggests the use of $\mathrm{H}_{3} \mathrm{PO}_{4} / \mathrm{H}_{2} \mathrm{OAC}$ for a series of pesticide-contaminated effluents, in which the Health Ministry Ordinance $N^{\circ} 2914$, of December $12^{\text {th }}, 201 \mathrm{I}$, dealing with the control and safety procedures of the water quality for human consumption and its potable standards, stablishes that the maximum limit for 2,4-D and FRD to be $30 \mu \mathrm{g} \cdot \mathrm{L}^{-1}$ and $7 \mu \mathrm{g} \cdot \mathrm{L}^{-1}$, respectively (BRASIL, 20I I).
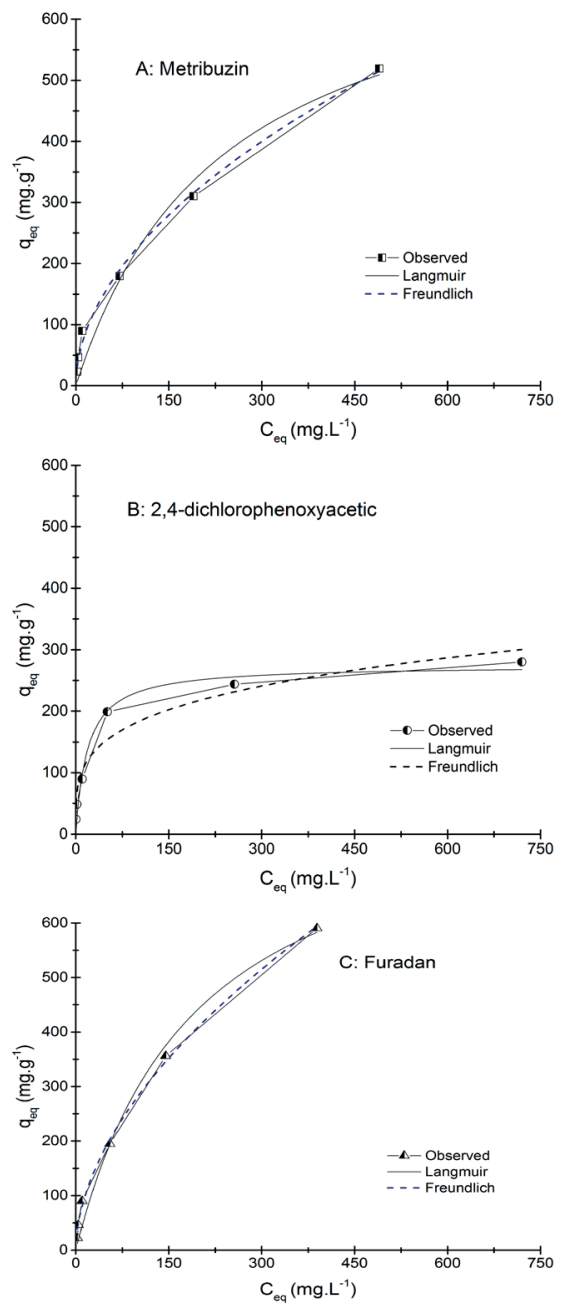

FIGURE 5 Adsorption isotherms for the pesticides (A) metribuzin, (B) 2,4-dichlorophenoxyacetic and (C) furadan for the produced AC ( $10 \mathrm{mg}$ of AC; $10 \mathrm{~mL}$ of different solution concentrations; $25^{\circ} \mathrm{C} ; \mathrm{q}_{\mathrm{eq}}=$ adsorbed contaminant quantity; $\mathrm{C}_{\mathrm{eq}}$ = balance concentration). 
For the MTZ, legislation about the allowed limit in Brazil was not found. However, the Environment Protection Agency (EPA) of the United States establishes as acceptable levels $200 \mu \mathrm{g} \cdot \mathrm{L}^{-1}$ of MTZ, based on the concentration of this pesticide in potable water, where it is not expected to cause adverse effects to human health at the course of one life (EPA, 2003).

\section{CONCLUSIONS}

The $\mathrm{H}_{3} \mathrm{PO}_{4} / \mathrm{H}_{2} \mathrm{OAC}$ had $39.00 \%$ yield, II 96.30 $\mathrm{m}^{2} \cdot \mathrm{g}^{-1} \mathrm{~S}_{\mathrm{BET}}$ and $0.61 \mathrm{~cm}^{3} \cdot \mathrm{g}^{-1} \mathrm{~V}_{\mathrm{p}}$ By the obtained results for the $S_{M}\left(884.88 \mathrm{~m}^{2} \cdot \mathrm{g}^{-1}\right)$ and I $\left(747.5 \mathrm{I} \mathrm{mg} \cdot \mathrm{g}^{-1}\right)$ it can be observed that the produced $A C$ is mainly microporous. Furthermore, it was efficient for removing the three analyzed pesticides, presenting high adsorption capacity for the FRD (868.98 $\left.\mathrm{mg} \cdot \mathrm{g}^{-1}\right)$, MTZ (756.47 $\left.\mathrm{mg} \cdot \mathrm{g}^{-1}\right)$ and 2,4-D (274.70 $\left.\mathrm{mg} \cdot \mathrm{g}^{-1}\right)$.

The results observed in this paper suggest the use of $\mathrm{H}_{3} \mathrm{PO}_{4} / \mathrm{H}_{2} \mathrm{OAC}$ to a series of pesticide-contaminated water bodies, mainly in higher concentrations than established limits permitted by legislation. Lastly, complementary researches should be made to perfect, even more, the quality of the produced $\mathrm{H}_{3} \mathrm{PO}_{4} / \mathrm{H}_{2} \mathrm{OAC}$.

\section{REFERENCES}

AMERICAN SOCIETY FOR TESTING AND MATERIALS. ASTM D 4607: standard test method for determination of iodine number of activated carbon. Pennsylvania, 1994, 5p.

ASSOCIAÇÃO BRASILEIRA DE NORMAS TÉCNICAS. EB 2133: carvão ativado pulverizado - especificação. Rio de Janeiro, 1991. 4p.

ASSOCIAÇÃO BRASILEIRA DE NORMAS TÉCNICAS. NBR 8I I 2: carvão vegetal - análise imediata. Rio de Janeiro, 1986. 5p.

AVELAR F. F.; BIANCHI, M. L.; GONÇALVES, M.; MOTA, E. G. The use of piassava fibers (Attalea funifera) in the preparation of activated carbon. Bioresource Technology, v. I0I, n. I2, p. $4639-4645,2010$.

BARBOSA, C. S.; SANTANA, S. A. A.; BEZERRA, C. W. B.; SILVA, H. A. S. Remoção de compostos fenólicos de soluções aquosas utilizando carvão ativado preparado a partir do aguapé (Eichhornia crassipes): estudo cinético e de equilíbrio termodinâmico. Quimica Nova, v. 37, n. 3, p. $447-453,2014$.

BAUTISTA-TOLEDO, I.; FERRO-GARCIA, M. A.; RIVERAUTRILLA, J.; MORENO-CASTILHA, C.; FERNÁNDEZ, J. $V$. Bisphenol A removal from water by activated carbon. Effects of carbon characteristics and solution chemistry. Environmental Science \& Technology, v. 39, n. 16, p. 6246-6250, 2005.
BAUTISTA-TOLEDO, M. I.; RIVERA-UTRILLA, J.; OCAMPOPÉREZ, R.; CARRASCO-MARÍN, F; SÁNCHEZ-POLO, M. Cooperative adsorption of bisphenol-A and chromium (III) ions from water on activated carbons prepared from olivemill waste. Carbon, v. 73, p. 338-350, 2014.

BOEHM, H. P. Some aspects of the surface chemistry of carbon blacks and other carbons. Carbon, v. 32, n. 5, p. 759-769, 1994.

BRASIL. Ministério da Saúde, Portaria $n^{\circ} 2914$ de 12 de dezembro de $201 \mathrm{I}$ - Dispõe sobre os procedimentos de controle e de vigilância da qualidade da água para consumo humano e seu padrão de potabilidade. Brasília, 20 I I.

BRUM, S. S.; BIANCHI, M. L.; SILVA, V. L.; GONÇALVES, M.; GUERREIRO, M. C.; OLIVEIRA, L. C. A. Preparação e caracterização de carvão ativado produzido a partir de resíduos do beneficiamento do café. Quimica Nova, v. 31, n. 5, p. 1048-1052, 2008

CARVAJAL-BERNAL, A. M.; GÓMEZ, F; GIRALDO, L.; MORENO-PIRAJÁN, J. C. Adsorption of phenol and 2,4-dinitrophenol on activated carbons with surface modifications. Microporous and Mesoporous Materials, v. 209, p. I50-156, 2015.

CHANG, K. L.; CHEN, C. C.; LIN, J. H.; HSIEN, J. F.; WANG, Y.; ZHAO, F.; SHIH, Y. H.; XING, Z. J.; CHEN, S. T. Rice strawderived activated carbons for the removal of carbofuran from an aqueous solution. New Carbon Materials, v. 29, n. I, p. 47-54, 2014.

COUTO, G. M.; DESSIMONI, A. L. A.; BIANCHI, M. L.; PERÍGOLO, D. M.; TRUGILHO, P. F. Use of sawdust Eucalyptus sp. in the preparation of activated carbons. Ciência e Agrotecnologia, v. 36, n. I, p. 69-77, 2012.

DIAS, J. M.; ALVIM-FERRAZ, M. C.; ALMEIDA, M. F.; RIVERAUTRILLA, J. R.; SÁNCHEZ-POLO, M. Waste materials for activated carbon preparation and its use in aqueousphase treatment: A review. Journal of Environmental Management, v. 85, p. 833-846, 2007.

HÚMPOLA, P.; ODETTI, H.; MORENO-PIRAJÁN, J. C.; GIRALDO, L. Activated carbons obtained from agro-industrial waste: textural analysis and adsorption environmental pollutants. Adsorption, v. 22, n. I, p. 23-31, 2016.

MEZOHEGYI, G.; ZEE, F. P. V. D.; FONT, J.; FORTUNY, A.; FABREGAT, A. Towards advanced aqueous dye removal processes: a short review on the versatile role of activated carbon. Journal of Environmental Management, v. I02, n. 15, p. 148-164, 2012.

NJOKU, V. O.; ISLAM, M. A.; ASIF, M.; HAMEED, B. H. Preparation of mesoporous activated carbon from coconut frond for the adsorption of carbofuran insecticide. Journal of Analytical and Applied Pyrolysis, v. I I0, p. 172-180, 2014b. 
NJOKU, V. O.; ISLAM, M. A.; ASIF, M.; HAMEED, B. H. Utilization of sky fruit husk agricultural waste to produce high quality activated carbon for the herbicide bentazon adsorption. Chemical Engineering Journal, v. 25I, p. |83-19|, 2014a.

NJOKU, V. O.; ISLAM, M. A.; ASIF, M.; HAMEED, B. H. Adsorption of 2,4-dichlorophenoxyacetic acid by mesoporous activated carbon prepared from $\mathrm{H}_{3} \mathrm{PO}_{4}-$ activated langsat empty fruit bunch. Journal of Environmental Management, v. I54, p. I38-|44, 2015.

NOBRE, J. R. C.; CASTRO, J. P.; MOTTA, J. P.; BIANCHI, M. L.; TRUGILHO, P. F.; BORGES, W. M. S.; MOULIN, J. C. Produção de carvão ativado de resíduos madeireiros da região Amazônica. Scientia Forestalis, v. 43, n. 108, p. 895-906, 2015.

RAMOS, P. H.; GUeRREIRO, M. C.; RESENDE, E. C.; GONÇALVES, M. Produção e caracterização de carvão ativado produzido a partir do defeito preto, verde, ardido (pva) do café. Quimica Nova, v. 32, n. 5, p. I I39-I I43, 2009.

RIBEIRO, A. S. Carvão de bambu como fonte energética e outras aplicações. Maceió: Instituto do Bambu, 2005. I40p.

SALES, D. C. S.; MARTINS, R. G.; JAGUARIBE, E. F.; ABREU, C. A. M. Formulation of activated carbons and evaluation of methane storage by compression and adsorption. The Canadian Journal of Chemical Engineering, v. 90, n. 3, p. 777-784, 2012.

SALMAN, J. M.; HAMEED, B. H. Adsorption of 2,4-dichlorophenoxyacetic acid and carbofuran pesticides onto granular activated carbon. Desalination, v. 256, p. 129-135, 2010.

SALMAN, J. M.; NJOKU, V. O.; HAMEED, B. H. Bentazon and carbofuran adsorption onto date seed activated carbon: Kinetics and equilibrium. Chemical Engineering Journal, v. I73, p. 36I-368, 201 I.
SANTOS, R. C.; CARNEIRO, A. C. O.; TRUGILHO, P. F.; MENDES, L. M.; CARVALHO, A. M. M. L. Análise termogravimétrica em clones de eucalipto como subsidio para a produção de carvão vegetal. Cerne, v. 18, n. I, p. |43-I5I, 2012.

SAUCIER, C.; ADEBAYO, M. A.; LIMA, E. C.; CATALUÑA, R.; THUE, P. S.; PROLA, L. D. T.; PUCHANA-ROSERO, M. J.; MACHADO, F. M.; PAVAN, F. A.; DOTTO, G. L. Microwave-assisted activated carbon from cocoa shell as adsorbent for removal of sodium diclofenac and nimesulide from aqueous effluents. Journal of Hazardous Materials, v. 289 , p. 18-27, 2015.

SKAAR, C. Wood-water relations. Springer-Verlag, 1988. 283p.

TIBURTINO, R. F.; PAES, J. B.; BERALDO, A. L.; ARANTES, M. D. C.; BROCCO, V. F. Tratamento preservativo de duas espécies de bambu por imersão prolongada e boucherie modificado. Floresta e Ambiente, v. 22, n. I, p. 124-133, 2015.

TRANSPARENCY MARKET RESEARCH. Activated carbon market. Available from: http://www. transparencymarketresearch.com. Accessed in: 18 may 2016.

UL HAQ, A.; SHAH, J.; HAN, M. R.; DIN, S. U. Kinetic, equilibrium and thermodynamic studies for the sorption of metribuzin from aqueous solution using banana peels, an agro-based biomass. Toxicological and Environmental Chemistry, v. 97, n. 2, p. I24-134, 2015.

UNITED STATES ENVIRONMENTAL PROTECTION AGENCY - EPA. Health effects support document for metribuzin. Washington: EPA, 2003.

WERNERT, V.; DENOYEL, R. Adsorption of styrene sulfonate from aqueous solution onto carbon fibers and mesoporous carbon. Microporous and Mesoporous Materials, v. 222, p. 247-255, 2016. 
